\title{
Mechanisms of action of angiotensin II on mammalian sperm function
}

\author{
Samra Mededovic and Lynn R Fraser \\ Centre for Reproduction, Endocrinology and Diabetes, School of Biomedical Sciences, King's College London, \\ Guy's Campus, London Bridge, London SE1 1UL, UK
}

Correspondence should be addressed to L R Fraser; Email: lynn.fraser@kcl.ac.uk

\begin{abstract}
Angiotensin II (AII) stimulates capacitation and fertilizing ability in mammalian spermatozoa, with the binding of AII to its receptors resulting in stimulation of cAMP production in both uncapacitated and capacitated cells. This study investigated possible mechanisms whereby AII affects cAMP availability. The first question was whether extracellular $\mathrm{Ca}^{2+}$ is required for responses in mouse spermatozoa and, using chlortetracycline fluorescence analysis, it was clear that cells responded to All only when the medium contained $\mathrm{CaCl}_{2}$, with both $90 \mu \mathrm{M}$ and $1.80 \mathrm{mM}$ supporting a significant acceleration of capacitation. Consistent with those results, All significantly stimulated cAMP production in both $\mathrm{CaCl}_{2}$-containing media tested, the response being greater in that containing $1.80 \mathrm{mM}$. Several different agents that might affect the signalling pathway stimulated by AII were then evaluated in uncapacitated suspensions. Chlortetracycline analysis revealed that pertussis toxin abolished responses to AII, suggesting the involvement of an inhibitory $\mathrm{G} \alpha$ subunit; dideoxyadenosine, a specific membrane-associated adenylyl cyclase (mAC) P-site inhibitor, also blocked responses, suggesting involvement of an mAC. cAMP determinations confirmed that both reagents also abolished AlI's stimulation of cAMP. In contrast, nifedipine, a Ca ${ }^{2+}$ channel blocker, did not inhibit All's effects on spermatozoa. Finally, in capacitated suspensions, both pertussis toxin and dideoxyadenosine were again shown to block AII's stimulation of cAMP. These results suggest that responses to AII involve an inhibitory $G$ protein and an mAC, but it is likely that AII-receptor coupling does not stimulate directly mAC but rather does so in an indirect manner, perhaps by altering the intracellular $\mathrm{Ca}^{2+}$ concentration.

Reproduction (2005) 129 211-218
\end{abstract}

\section{Introduction}

Although the peptide angiotensin II (AII) is generally known for its roles in regulating cardiovascular and electrolyte homeostasis (Vinson et al. 1997), All is also found in seminal plasma at concentrations higher than in blood (O'Mahony et al. 2000). This suggests that All might be able to act on mammalian spermatozoa, in addition to other somatic cells and tissues. Several recent studies have confirmed this for both mouse (Fraser et al. 2001) and human (Fraser \& Osiguwa 2004) spermatozoa, with All being shown to accelerate capacitation, but not to inhibit spontaneous acrosome loss, in both species. In contrast, other small molecules found in seminal plasma, including adenosine, calcitonin and fertilization-promoting peptide (FPP; pGlu-Glu-Pro- $\mathrm{NH}_{2}$ ), have likewise been shown to act on mammalian spermatozoa, with all of these molecules first accelerating capacitation in uncapacitated cells and then inhibiting spontaneous acrosome loss in capacitated cells (Fraser et al. 2003, Fraser \&
Osiguwa 2004). Therefore adenosine, calcitonin and FPP can regulate capacitation, whereas All can only stimulate it.

Despite those differences in responses elicited by All and the other small molecules in capacitated spermatozoa, combinations of low concentrations of All plus FPP or calcitonin, ineffective if used individually, were shown to significantly accelerate capacitation (Fraser et al. 2001, Fraser \& Osiguwa 2004). These results therefore suggested that all three peptides were working on the same or related signal transduction pathways. FPP, adenosine and calcitonin have been shown to regulate membrane-associated adenylyl cyclase (mAC)/cAMP, first stimulating cAMP production in uncapacitated cells and then inhibiting cAMP in capacitated cells (Fraser et al. 2003). This made it plausible that All was also affecting cAMP production and this has now been confirmed in a recent study (Mededovic \& Fraser 2004) where All was shown to stimulate CAMP in both uncapacitated and capacitated spermatozoa. In that same study, AT1 receptors for All 
were found to be located in the acrosomal cap region and along the whole of the flagellum in both mouse and human spermatozoa, consistent with the enhanced fertility observed in All-treated mouse sperm suspensions (Fraser et al. 2001); successful fertilization requires changes in both the sperm head and flagellum. All-induced stimulation of cAMP production was associated with increases in protein tyrosine phosphorylation, as determined by immunolocalization of tyrosine phosphoproteins in the head and flagellum of individual cells and by Western blotting of sperm homogenates (Mededovic \& Fraser 2004). There was evidence for capacitation-related differences both in the relative abundance of tyrosine phosphoproteins in the two compartments of intact spermatozoa and in the specific tyrosine phosphoproteins affected in response to All.

Although the study by Mededovic \& Fraser (2004) confirmed that responses to All involve a significant stimulation of CAMP production, it did not provide information on what elements might be involved in the signalling pathway. Current evidence (Fraser et al. 2003) suggests that the binding of FPP, calcitonin and adenosine to their respective receptors results in a $\mathrm{G}$ protein-mediated regulation of $\mathrm{mAC}$, with the stimulatory responses involving $\mathrm{G} \alpha_{\mathrm{s}}$ and the inhibitory responses involving $\mathrm{G} \alpha_{\mathrm{i}}$ (possibly $\left.\mathrm{G} \alpha_{\mathrm{i} 2}\right)$; both $\mathrm{G} \alpha_{\mathrm{s}}$ and $\mathrm{G} \alpha_{\mathrm{i} 2}$ are found in the same regions as those receptors (Baxendale \& Fraser 2003a). Immunolocalization studies have identified the presence of several $\mathrm{mACs}$, with $\mathrm{mAC2}, 3$ and 8 being most abundant and $\mathrm{mAC} 1$ and 4 less so; mAC3 and 8 were located in both the acrosomal cap region and in the flagellum where calcitonin and adenosine receptors are also found (Baxendale \& Fraser 2003b). While All continuously stimulates cAMP, combinations of All and FPP/calcitonin result in inhibition of the spontaneous acrosome reaction, indicating that the inhibitory effects on cAMP production can override the stimulatory ones. This might suggest that All-receptor coupling acts in an indirect manner, rather than stimulating $\mathrm{mAC}$ directly. The present study was undertaken to investigate the possible involvement of extracellular $\mathrm{Ca}^{2+}$, $\mathrm{G}$ proteins, mACs and $\mathrm{Ca}^{2+}$ channels in the signalling pathway activated by All.

\section{Materials and Methods}

All animals used in this study were maintained in Home Office-approved facilities.

\section{Media and reagents}

A modified Tyrode's medium (Fraser 1993) containing $1.80 \mathrm{mM} \mathrm{CaCl}_{2}$ (in most experiments) and $4 \mathrm{mg} / \mathrm{ml} \mathrm{BSA}$ was used; unless otherwise specified, all reagents were obtained from Sigma (Poole, Dorset, UK). Stock solutions of human All were prepared in medium, divided into aliquots, frozen and kept at $-20^{\circ} \mathrm{C}$. FPP solutions were prepared as described previously (Green et al. 1994), lyophilized and stored at $-20^{\circ} \mathrm{C}$. For use, samples were reconstituted in BSA-free medium, aliquoted and frozen; these were used within 1 month. 2', 5'-Dideoxyadenosine (ddAdo; Calbiochem-Novabiochem, Beeston, Nottingham, UK) solutions were prepared in DMSO, aliquoted and frozen. Stock solutions of guanosine $5^{\prime}$-[ $\gamma$-thio]triphosphate (GTP $y S$ ) in PBS, nifedipine in absolute ethanol and the cyclic nucleotide phosphodiesterase inhibitor Ro-20-1724 in DMSO were prepared daily. Each was diluted in complete medium to ensure that the final DMSO concentration was $\leq 1 \%$, a concentration shown to have no adverse effects on sperm function. Pertussis toxin (PT) at $100 \mu \mathrm{g} / \mathrm{ml}$ was prepared in distilled water and stored at $4{ }^{\circ} \mathrm{C}$; for use, it was diluted $1 / 20$ in modified Tyrode's medium and then used. In all experiments, the final working stock of reagent was 50 times the final desired concentration.

\section{Sperm suspension preparation}

Mouse sperm suspensions were prepared using mature male TO mice (Harlan UK, Bicester, Oxon, UK); all suspensions contained spermatozoa from at least two or three males. The cauda epididymides were removed and the contents were extruded into a $30 \mathrm{~mm}$ sterile culture dish (Nunc, Roskilde, Denmark) containing modified Tyrode's medium $(0.8 \mathrm{ml}$ medium per pair of caudae). Suspensions were maintained on a warming tray (approximately $37^{\circ} \mathrm{C}$ ) and allowed to disperse for $5 \mathrm{~min}$. In experiments using uncapacitated spermatozoa, suspensions were used immediately while in experiments using capacitated cells, suspensions were incubated for approximately $90 \mathrm{~min}$ under autoclaved liquid paraffin (Boots, Nottingham, UK) at $37^{\circ} \mathrm{C}$ in an atmosphere of $5 \%$ $\mathrm{CO}_{2} / 5 \% \mathrm{O}_{2} / 90 \% \mathrm{~N}_{2}$. Just prior to use, suspensions were filtered through short columns (Pasteur pipettes plugged with a small amount of glass wool) of Sephadex G-25 (medium grade, pre-equilibrated with medium; Amersham Biosciences) to remove non-motile cells. Suspensions are filtered to remove non-motile cells because vital stains to determine live/dead status cannot be used with mouse spermatozoa. Free stain must be removed by centrifugation and uncapacitated mouse spermatozoa cannot be centrifuged because this removes a decapacitation factor and so accelerates capacitation even before experimental treatment begins (Fraser 1984). Filtrates were pooled, checked for satisfactory motility (approximately 90\% motile), and then treated immediately as detailed in the Experimental design and results section.

Mouse spermatozoa preincubated for 90-120 min in this manner have been shown to be capacitated, as evidenced by chlortetracycline (CTC) analysis (e.g. Fraser et al. 2001), in vitro fertilization (e.g. Fraser 1987) and tyrosine phosphorylation analysis (Adeoya-Osiguwa \& Fraser 2000, Mededovic \& Fraser 2004).

\section{CTC fluorescence analysis}

The functional state of spermatozoa following experimental treatment was assessed using the CTC fluorescence 
assay as described by Fraser and Adeoya-Osiguwa (1999). An Olympus BX41 microscope (Olympus Optical Co (UK), London, UK) equipped with phase-contrast and epifluorescent optics was used to evaluate the cells, using the U-MWBV2 fluorescence cube (wide blue-violet) to assess CTC patterns. In each sample, 100 spermatozoa were classified as showing one of three staining patterns: $F$, with fluorescence over the entire head that is characteristic of uncapacitated, acrosome-intact spermatozoa; B, with a fluorescence-free band in the post-acrosomal region that is characteristic of capacitated, acrosome-intact spermatozoa; and AR, with dull or absent fluorescence over the entire head that is characteristic of acrosomereacted spermatozoa.

In all experiments using CTC analysis, suspensions were incubated in the absence/presence of test reagents for approximately $35 \mathrm{~min}$, then stained and analysed; this length of incubation is sufficient to determine whether the treatment has had a detectable effect. This is important, especially with uncapacitated suspensions, because with more extended treatment times the controls will be capacitating and this makes it more difficult to detect significant responses due to the experimental treatment.

\section{cAMP measurements}

The amount of cAMP produced in live, intact cells was determined using a non-radioactive enzyme immunoassay kit from Amersham Biosciences. Assays, in triplicate for each treatment in each replicate experiment, were performed as described in the instructions provided with the kit. Earlier studies have shown that when treatments cause a stimulation in CAMP production, a significant effect can be observed within 2 min in uncapacitated suspensions and within $5 \mathrm{~min}$ in capacitated suspensions (Fraser \& Adeoya-Osiguwa 1999).

\section{Statistical analysis}

Cochran's modification of the $\chi^{2}$ test (Snedecor \& Cochran 1980) was used to analyse CTC data; since this test compares responses within individual replicates, a response will only be significant if it is consistent and of sufficient magnitude in the replicate experiments. A paired t-test (Sigma Stats, Jandell Scientific International, Chicago, IL, USA) was used to analyse data from cAMP determinations.

\section{Experimental design and results}

\section{Series I: do responses to AII in uncapacitated spermatozoa require extracellular $\mathrm{Ca}^{2+}$ ?}

This series was undertaken to determine whether responses to All require $\mathrm{Ca}^{2+}$ in the medium. Earlier studies have shown that epididymal mouse spermatozoa require at least $90 \mu \mathrm{M} \mathrm{CaCl} 2$ to support capacitation, whereas $1.80 \mathrm{mM}$ is the optimal concentration for support of capacitation, acrosome loss and fertilization. Sperm suspensions were prepared in $\mathrm{Ca}^{2+}$-deficient medium, filtered and then divided into three aliquots; a concentrated stock containing $\mathrm{CaCl}_{2}$ was added to two of these to give final concentrations of $90 \mu \mathrm{M}$ and $1.80 \mathrm{mM} \mathrm{CaCl}{ }_{2}$. Each of these three suspensions was then divided into two, with All being added to one to give a final concentration of $10 \mathrm{nM}$. Suspensions were incubated for $35 \mathrm{~min}$, stained with CTC, fixed and evaluated; three replicate experiments were carried out $(n=3)$. As shown in Fig. 1, All had no detectable effect on spermatozoa in the $\mathrm{Ca}^{2+}$ deficient medium, but it significantly accelerated capacitation in cells incubated in media containing $90 \mu \mathrm{M}$ and $1.80 \mathrm{mM} \mathrm{CaCl}_{2}$.

Since a recent study demonstrated that All significantly stimulates the production of CAMP (Mededovic \& Fraser 2004), we hypothesized that cAMP would be stimulated in spermatozoa prepared in both $90 \mu \mathrm{M}$ and $1.80 \mathrm{mM}$ $\mathrm{CaCl}_{2}$. Uncapacitated suspensions were prepared as above (initial suspensions were in $\mathrm{Ca}^{2+}$-deficient medium, divided and then $\mathrm{CaCl}_{2}$ stock solution was added to give the required $\mathrm{Ca}^{2+}$ concentration) and filtered; each was then divided into two and treated with either (1) nothing (control) or (2) $10 \mathrm{nM}$ All. Just prior to treatment, the phosphodiesterase inhibitor Ro-20-1724 (5 $\mu \mathrm{M}$ final concentration) was added to each sample. After an incubation for $2 \mathrm{~min}$ at $37^{\circ} \mathrm{C}$, the reaction was stopped by transferring $200 \mu \mathrm{l}$ of each suspension into tubes containing reagents to give final concentrations of $4 \mathrm{mM}$ EDTA $/ 0.2 \mu \mathrm{g} / \mathrm{ml}$ leupeptin $/ 400 \mathrm{mg} / \mathrm{ml}$ trypsin inhibitor and then freezing samples in liquid $\mathrm{N}_{2}$. After thawing samples at room temperature, cAMP was extracted with ethanol and determinations were carried out as recommended in the kit instruction booklet $(n=6-8)$. All significantly stimulated the production of CAMP in both media tested, but the degree of stimulation was greater in medium containing $1.80 \mathrm{mM} \mathrm{CaCl}_{2}$ (Fig. 2).

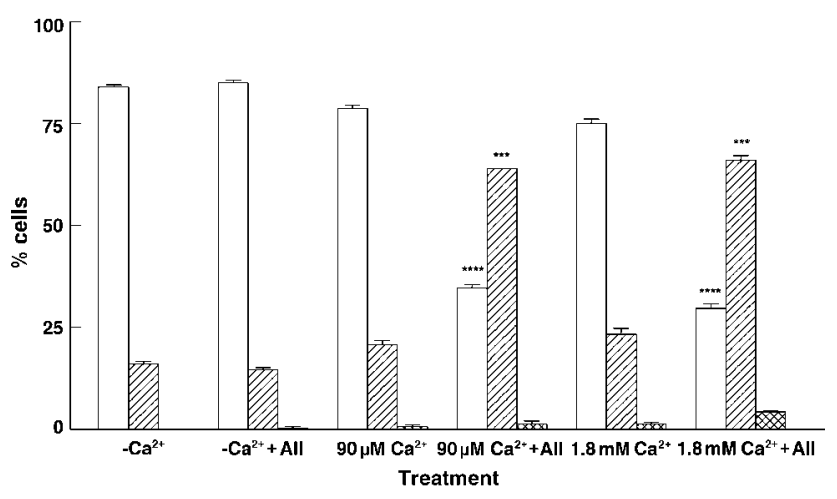

Figure 1 All requires the presence of $\geq 90 \mu \mathrm{M} \mathrm{CaCl}_{2}$ in order to elicit significant responses in uncapacitated sperm suspensions; cells were incubated for $35 \mathrm{~min}$, then assessed using CTC fluorescence. Data are presented as the percentage of cells (mean \pm S.E.; $n=3$ ) expressing the $\mathrm{F}$ pattern (white bars), the B pattern (hatched bars) and the AR pattern (cross-hatched bars) of CTC fluorescence. ${ }^{* * *} P<0.01$, ${ }_{* * * *} P<0.001$ compared with untreated controls. 


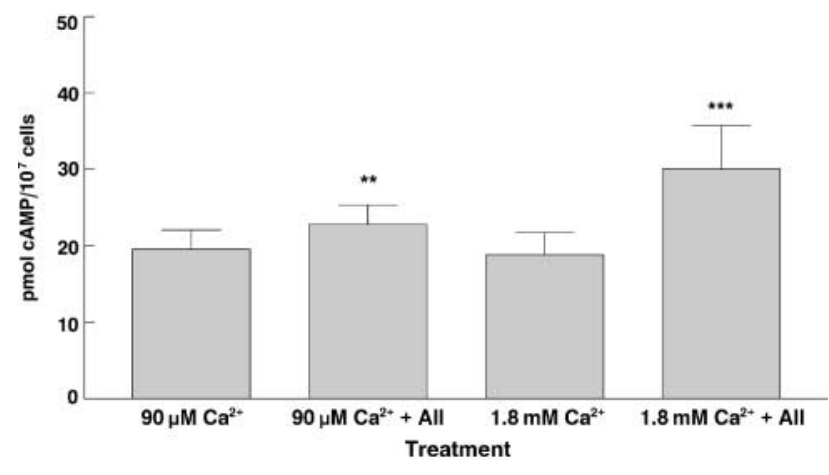

Figure 2 All significantly stimulates CAMP production in spermatozoa incubated in medium containing $90 \mu \mathrm{M}$ and $1.80 \mathrm{mM} \mathrm{CaCl}_{2}$; cAMP content was measured after $2 \mathrm{~min}$. Data are presented as pmol CAMP $/ 10^{7}$ cells (mean \pm S.E.; $n=6-8$ ). ${ }^{* *} P<0.025,{ }^{* * *} P<0.01$ compared with relevant control suspensions.

\section{Series II: do GTP $\gamma$ S and nifedipine have any effect on responses to All in uncapacitated spermatozoa?}

To investigate the possible involvement of $G$ proteins and $\mathrm{Ca}^{2+}$ channels, the effects of GTP $\gamma \mathrm{S}$, a non-hydrolysable GTP analogue that gives persistent $G$ protein stimulation, and nifedipine, an L-type $\mathrm{Ca}^{2+}$ channel blocker, on responses to All were evaluated. Uncapacitated suspensions were prepared, filtered and divided into six aliquots for treatment: (1) none (control); (2) $10 \mathrm{nM} \mathrm{All;} \mathrm{(3)} 50 \mu \mathrm{M}$ GTP $\gamma$ S; (4) $10 \mathrm{nM}$ All $+50 \mu \mathrm{M}$ GTP $\gamma$ S; (5) $100 \mathrm{nM}$ nifedipine; (6) $10 \mathrm{nM} \mathrm{All}+100 \mathrm{nM}$ nifedipine. Suspensions were incubated for $35 \mathrm{~min}$ at $37^{\circ} \mathrm{C}$, stained with CTC, fixed and assessed $(n=4)$.

Used individually, both AII and GTP $\gamma$ S significantly accelerated capacitation when compared with untreated control suspensions, while nifedipine had no detectable effect (Fig. 3). In the combined treatment groups, the

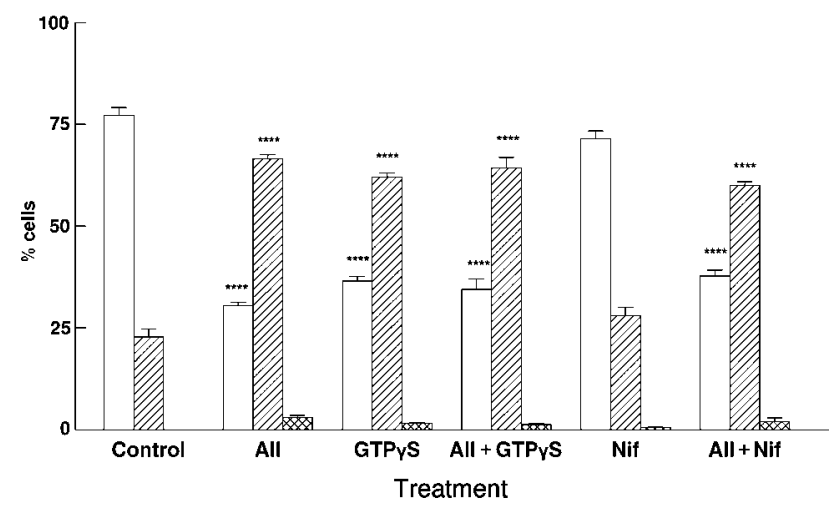

Figure $3 \mathrm{GTP} \gamma \mathrm{S}$ and nifedipine do not block responses to All in uncapacitated sperm suspensions incubated for $35 \mathrm{~min}$ following addition of (1) nothing (Control), (2) $10 \mathrm{nM} \mathrm{All,} \mathrm{(3)} 50 \mu \mathrm{M}$ GTP $\gamma \mathrm{S}$, (4) $10 \mathrm{nM}$ $\mathrm{All}+50 \mu \mathrm{M} \mathrm{GTP} \gamma \mathrm{S}$, (5) $100 \mathrm{nM}$ nifedipine (Nif) and (6) $10 \mathrm{nM}$ All $+100 \mathrm{nM} \mathrm{Nif}$; cells were then assessed using CTC fluorescence. Data are presented as the percentage of cells (mean \pm S.E.; $n=4$ ) expressing the $\mathrm{F}$ pattern (white bars), the B pattern (hatched bars) and the AR pattern (cross-hatched bars) of CTC fluorescence. $* * * * P<0.001$ compared with untreated controls. responses in All + GTP $\gamma \mathrm{S}$ were very similar to those seen in suspensions treated with one or the other and the responses in All + nifedipine were essentially the same as those seen in All-only treated suspensions. There was no evidence that either GTP $\gamma S$ or nifedipine blocked the action of All. The fact that GTP $\gamma S$ can mimic responses to All is consistent with the involvement of $G$ proteins, while the failure of nifedipine to block action by All suggests that $\mathrm{Ca}^{2+}$ channels are not involved in responses to All.

\section{Series III: do PT and ddAdo interfere with responses to AII in uncapacitated spermatozoa?}

The previous series suggested involvement of $G$ proteins, but GTP $\gamma S$ is not specific for either stimulatory or inhibitory G proteins. Therefore, PT, which irreversibly inactivates a number of inhibitory $\mathrm{G} \alpha$ subunits, was evaluated. Given that All stimulates CAMP production, it also seemed reasonable to investigate the effect of ddAdo, an inhibitor of $\mathrm{mAC}$, on responses to All. Uncapacitated mouse sperm suspensions were prepared in complete Tyrode's medium, filtered and divided into aliquots for treatment: (1) no treatment (control); (2) $10 \mathrm{nM} \mathrm{All;} \mathrm{(3)} 100 \mathrm{ng} / \mathrm{ml} \mathrm{PT;} \mathrm{(4)}$ $10 \mathrm{nM}$ All $+100 \mathrm{ng} / \mathrm{ml} \mathrm{PT}$; (5) $100 \mu \mathrm{M}$ ddAdo; (6) $10 \mathrm{nM}$ All $+100 \mu \mathrm{M}$ ddAdo. After incubation at $37^{\circ} \mathrm{C}$ for $35 \mathrm{~min}$, samples were stained with CTC, fixed and assessed $(n=4)$.

All significantly accelerated capacitation, while PT and ddAdo used individually had no detectable effect (Fig. 4). However, when All was tested in combination with either PT or ddAdo, responses to All were abolished. Since PT is known to inhibit many of the inhibitory $\mathrm{G} \alpha$ subunits and ddAdo is a specific mAC P-site inhibitor (Dessauer et al. 1999), these results suggest that both a PT-sensitive

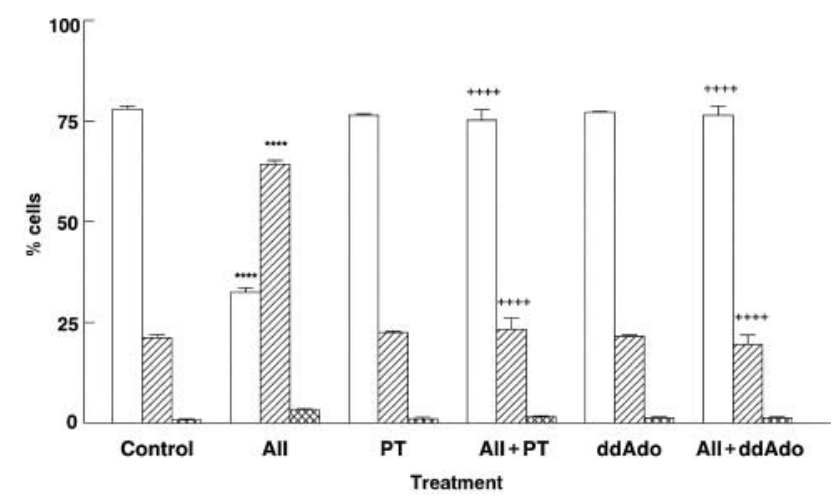

Figure 4 PT and ddAdo block responses to All in uncapacitated sperm suspensions incubated for $35 \mathrm{~min}$ following addition of (1) nothing (Control), (2) $10 \mathrm{nM}$ All, (3) $100 \mathrm{ng} / \mathrm{ml} \mathrm{PT,} \mathrm{(4)} 10 \mathrm{nM}$ All $+100 \mathrm{ng} / \mathrm{ml} \mathrm{PT,} \mathrm{(5)} 100 \mu \mathrm{M}$ ddAdo and (6) $10 \mathrm{nM} \mathrm{All}+100 \mu \mathrm{M}$ ddAdo; cells were then assessed using CTC fluorescence. Data are presented as the percentage of cells (mean \pm S.E.; $n=4$ ) expressing the $F$ pattern (white bars), the B pattern (hatched bars) and the AR pattern (cross-hatched bars) of CTC fluorescence. ${ }^{* * * *} P<0.001$ compared with untreated controls, ${ }^{++++} P<0.001$ compared with suspensions receiving $10 \mathrm{nM}$ All. 
inhibitory $\mathrm{G} \alpha$ subunit and an mAC may be involved in the sequence of events leading to stimulation of cAMP production by All.

Because responses to All and FPP in uncapacitated cells are the same, namely acceleration of capacitation resulting from increased cAMP, the ability of PT to block responses to All in uncapacitated spermatozoa was surprising. PT had no effect on uncapacitated sperm responses to FPP, while it abolished responses in capacitated sperm suspensions (Fraser \& Adeoya-Osiguwa 1999). To confirm that the present results with PT were valid, a second set of experiments was undertaken to compare responses in uncapacitated sperm suspensions to All and FPP with or without PT. Treatments were: (1) none (control); (2) $10 \mathrm{nM} \mathrm{All;} \mathrm{(3)} 10 \mathrm{nM} \mathrm{All}+100 \mathrm{ng} / \mathrm{ml}$ PT; (4) $100 \mathrm{nM} \mathrm{FPP;} \mathrm{(5)} 100 \mathrm{nM} \mathrm{FPP}+100 \mathrm{ng} / \mathrm{ml}$ PT. After incubation at $37^{\circ} \mathrm{C}$ for $35 \mathrm{~min}$, samples were stained with CTC, fixed and assessed $(n=3)$. As shown in Fig. 5, both All and FPP significantly accelerated capacitation; PT was again able to block responses to All but had no effect on responses to FPP, thus confirming the earlier studies using FPP and validating the effects of PT on responses to All.

To obtain evidence that inhibition of responses to All by PT and ddAdo detected with CTC analysis reflects altered production of CAMP, uncapacitated suspensions were prepared as above and treated with: (1) nothing (control); (2) $10 \mathrm{nM} \mathrm{All}$; (3) $10 \mathrm{nM} \mathrm{All}+100 \mathrm{ng} / \mathrm{ml} \mathrm{PT;} \mathrm{(4)} 10 \mathrm{nM}$ All $+100 \mu \mathrm{M}$ ddAdo. Samples were incubated at $37^{\circ} \mathrm{C}$ for $2 \mathrm{~min}$, the reaction was stopped and samples were assayed for cAMP content $(n=3-6)$. All significantly stimulated CAMP production, compared with the untreated controls, but the inclusion of PT or ddAdo abolished this response (Fig. 6).

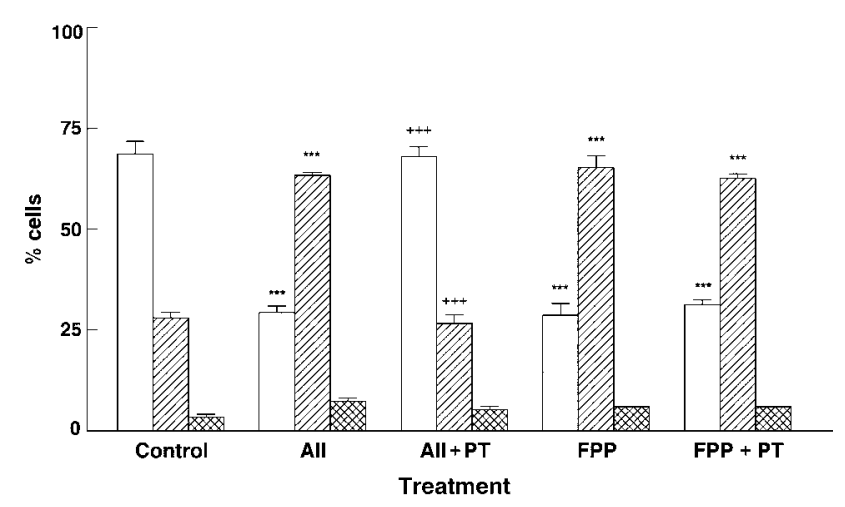

Figure 5 PT blocks responses to All but not to FPP in uncapacitated sperm suspensions incubated for $35 \mathrm{~min}$ following addition of (1) nothing (Control), (2) $10 \mathrm{nM} \mathrm{All,} \mathrm{(3)} 10 \mathrm{nM} \mathrm{All} \mathrm{+} 100 \mathrm{ng} / \mathrm{ml} \mathrm{PT}$, (4) $100 \mathrm{nM}$ FPP and (5) $100 \mathrm{nM} \mathrm{FPP}+100 \mathrm{ng} / \mathrm{ml} \mathrm{PT}$; cells were then assessed using CTC fluorescence. Data are presented as the percentage of cells (mean \pm S.E.; $n=3$ ) expressing the F pattern (white bars), the B pattern (hatched bars) and the AR pattern (cross-hatched bars) of CTC fluorescence. ${ }^{* * *} P<0.01$ compared with untreated controls, ${ }^{+++} P<0.01$ compared with All-treated suspensions.

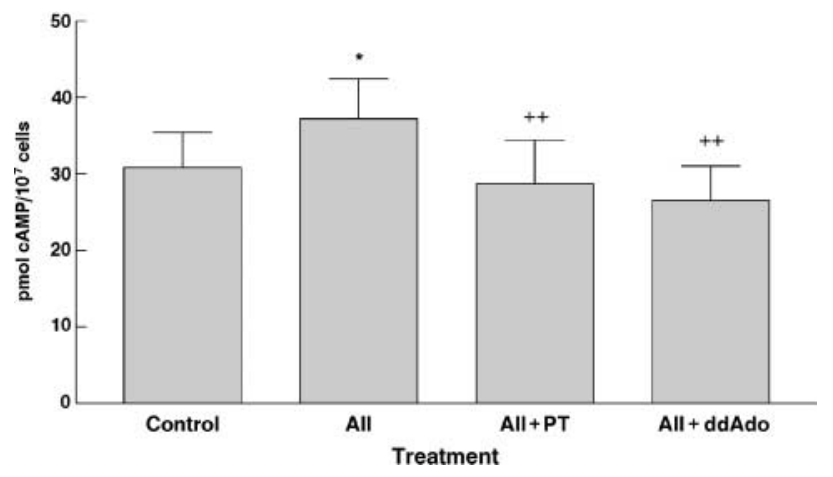

Figure 6 PT and ddAdo abolish All's stimulation of cAMP production in uncapacitated mouse sperm suspensions treated for $35 \mathrm{~min}$ with (1) nothing (Control), (2) $10 \mathrm{nM} \mathrm{All,} \mathrm{(3)} 10 \mathrm{nM} \mathrm{All} \mathrm{+} 100 \mathrm{ng} / \mathrm{ml}$ PT and (4) $10 \mathrm{nM}$ All $+100 \mu \mathrm{M}$ ddAdo; cAMP content was measured after $2 \mathrm{~min}$. Data are presented as pmol cAMP $/ 10^{7}$ cells (mean \pm S.E.; $n=3-6) . * P<0.05$ compared with untreated controls,

${ }^{++} P<0.025$ compared with compared with All-treated suspensions.

\section{Series IV: do GTP $\gamma$ S, PT and ddAdo have any effect on responses to All in capacitated spermatozoa?}

Having evaluated several reagents on uncapacitated suspensions, it was appropriate to consider effects on capacitated cells. Capacitated suspensions were prepared as described in the Materials and Methods section, filtered and divided into five aliquots for treatment: (1) none (control); (2) $10 \mathrm{nM} \mathrm{All;} \mathrm{(3)} 10 \mathrm{nM} \mathrm{All}+50 \mu \mathrm{M}$ GTP $\gamma$; (4) $10 \mathrm{nM} \mathrm{All}+100 \mathrm{ng} / \mathrm{ml} \mathrm{PT}$; (5) $10 \mathrm{nM} \mathrm{All}+100 \mu \mathrm{M}$ ddAdo. Suspensions were incubated for $35 \mathrm{~min}$ at $37^{\circ} \mathrm{C}$, stained with CTC, fixed and assessed $(n=4)$. While none of the experimental treatments produced results that differed significantly from the untreated controls, the distribution of $F, B$ and AR patterns of CTC fluorescence indicate that there were fewer $\mathrm{F}$ pattern and more AR pattern cells in the suspensions treated with All and All + GTP $\gamma S$ than in the controls (Fig. 7). In contrast, the relative proportions of $\mathrm{F}, \mathrm{B}$ and $\mathrm{AR}$ in the All + PT and All + ddAdo suspensions were very similar to those seen in the controls, suggesting that PT and ddAdo were inhibiting responses to All. It was therefore decided to evaluate the effects of All with or without PT and ddAdo on cAMP production, which is probably a more sensitive analytical approach.

Capacitated suspensions were prepared, filtered and divided into four groups for treatment: (1) none (control); (2) $10 \mathrm{nM} \mathrm{All;}$; 3) $10 \mathrm{nM} \mathrm{All}+100 \mathrm{ng} / \mathrm{ml} \mathrm{PT}$; (4) $10 \mathrm{nM}$ All $+100 \mu \mathrm{M}$ ddAdo. Suspensions were incubated at $37^{\circ} \mathrm{C}$ for $5 \mathrm{~min}$, the reaction was stopped and samples were assayed for cAMP content $(n=4)$. All significantly stimulated CAMP production, compared with the untreated controls, but the inclusion of either PT or ddAdo abolished this response (Fig. 8). Thus PT and ddAdo are able to block responses to All in both uncapacitated and capacitated cells. 


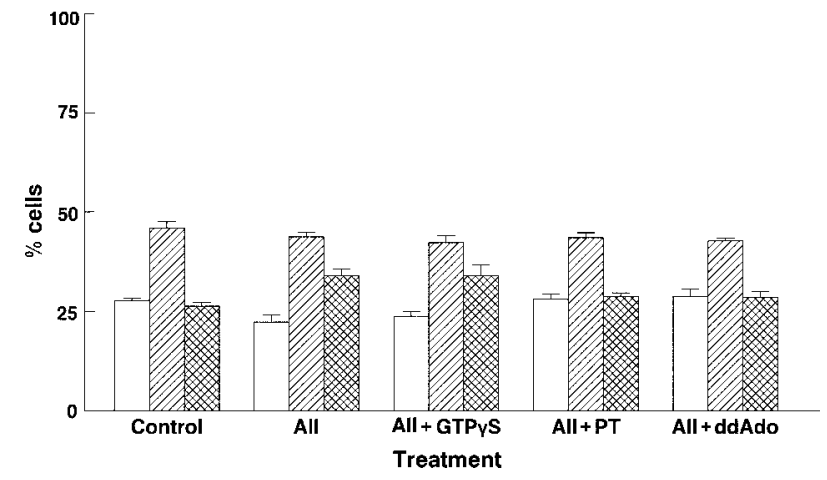

Figure 7 Responses to All with or without GTP $\gamma$ S, PT and ddAdo in capacitated spermatozoa suggest that PT and ddAdo inhibit responses to All. Capacitated suspensions were incubated for $35 \mathrm{~min}$ following addition of (1) nothing (Control), (2) $10 \mathrm{nM} \mathrm{All,} \mathrm{(3)} 10 \mathrm{nM}$

All $+50 \mu \mathrm{M} \mathrm{GTP \gamma S}$ (4), (5) $10 \mathrm{nM} \mathrm{All}+100 \mathrm{ng} / \mathrm{ml}$ PT and (6) $10 \mathrm{nM}$ All $+100 \mu \mathrm{M}$ ddAdo, then assessed using CTC fluorescence. Data are presented as the percentage of cells (mean \pm S.E.; $n=4)$ expressing the $\mathrm{F}$ pattern (white bars), the B pattern (hatched bars) and the AR pattern (cross-hatched bars) of CTC fluorescence.

\section{Discussion}

This study was conducted to obtain more information about the mechanism(s) whereby All stimulates the production of cAMP throughout capacitation. Earlier evidence suggested that All, calcitonin and FPP were all working on the same, or at least related, signalling pathways and indeed all have now been shown to stimulate cAMP production in uncapacitated cells. However, both calcitonin and FPP inhibit cAMP production in capacitated cells, leading to inhibition of spontaneous acrosome loss, while All continues to stimulate cAMP in capacitated cells and so does not inhibit the acrosome reaction. Therefore, it seems likely that the specific mechanisms used by All to continuously stimulate CAMP and capacitation differ from those used by calcitonin and FPP to regulate

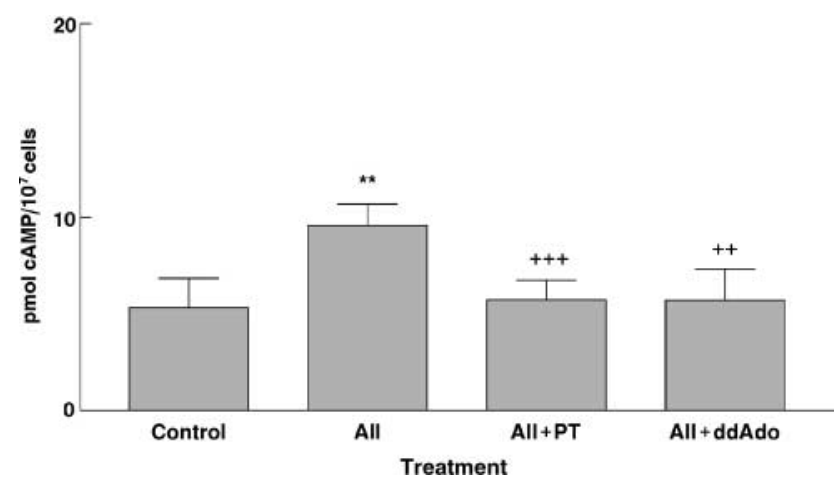

Figure 8 PT and ddAdo abolish All's stimulation of cAMP production in capacitated mouse sperm suspensions treated with (1) nothing (Control), (2) $10 \mathrm{nM} \mathrm{All,} \mathrm{(3)} 10 \mathrm{nM} \mathrm{All}+100 \mathrm{ng} / \mathrm{ml}$ PT and (4) $10 \mathrm{nM}$ All $+100 \mu \mathrm{M}$ ddAdo; CAMP content was assayed after 5 min. Data are presented as pmol cAMP $/ 10^{7}$ cells (mean \pm S.E.; $n=4$ ). ${ }^{* *} P<0.025$ compared with untreated controls, ${ }^{++} P<0.025$, ${ }^{++}+P<0.01$ compared with All-treated suspensions. capacitation. Possible components considered were extracellular $\mathrm{Ca}^{2+}, \mathrm{G}$ proteins, mACs and $\mathrm{Ca}^{2+}$ channels.

Extracellular $\mathrm{Ca}^{2+}$ is known to be required for complete capacitation and subsequent fertilization in mammals (Yanagimachi 1994). $\mathrm{Ca}^{2+}$-deficient Tyrode's medium, with no added $\mathrm{CaCl}_{2}$, contains trace amounts of approximately $13 \mu \mathrm{M} \mathrm{Ca}^{2+}$ (Fraser 1982), insufficient to support capacitation in most species. Mouse spermatozoa must have at least $90 \mu \mathrm{M} \mathrm{CaCl}_{2}$ in order to undergo complete capacitation, while optimal fertilizing ability requires $1.80 \mathrm{mM} \mathrm{CaCl}$ (Fraser 1987). Calcitonin and FPP have been shown to differ in their $\mathrm{Ca}^{2+}$ requirements to elicit biological responses: FPP must have at least $90 \mu \mathrm{M}$ while calcitonin can act in $\mathrm{Ca}^{2+}$-deficient medium that contains only traces of $\mathrm{Ca}^{2+}$ (Green et al. 1996). It therefore seemed reasonable to determine whether biological responses to All required the presence of added $\mathrm{Ca}^{2+}$. Results revealed that All, like FPP, also needs extracellular $\mathrm{Ca}^{2+}$; CTC analysis of suspensions showed that in $\mathrm{Ca}^{2+}$-deficient medium All could not affect capacitation, but in medium containing either $90 \mu \mathrm{M}$ or $1.80 \mathrm{mM} \mathrm{CaCl} 2$ All did significantly accelerate capacitation. Subsequent CAMP assays confirmed that in medium containing added $\mathrm{CaCl}_{2}$ All stimulated cAMP production, the stimulation being greater in the medium containing $1.80 \mathrm{mM} \mathrm{CaCl}_{2}$. The need to have extracellular $\mathrm{Ca}^{2+}$ could reflect involvement of an $\mathrm{mAC}$ that requires $\mathrm{Ca}^{2+}$ for function. Indeed, it has been proposed that the differential $\mathrm{Ca}^{2+}$ requirements for FPP and calcitonin to elicit biological responses indicates involvement of two different mACs (Adeoya-Osiguwa \& Fraser 2003); this is plausible, given that mACs are known to differ in their sensitivity to $\mathrm{Ca}^{2+}$ (Hanoune \& Defer 2001). However, from the present results it was not possible to determine whether All acts directly on mAC or indirectly, possibly by somehow causing an increase in the intracellular $\left[\mathrm{Ca}^{2+}\right]$ which could then stimulate mAC. Subsequent experiments explored these possibilities.

In many somatic cell types, the binding of All to the AT1 receptor activates a $G$ protein which then interacts with a specific effector (usually an enzyme) to complete a signal transduction pathway (Vinson et al. 1997, Sayeski et al. 1998). When uncapacitated sperm suspensions were incubated with the GTP analogue GTP $\gamma$ S, which would irreversibly activate $\mathrm{G} \alpha$ subunits, CTC analysis revealed accelerated capacitation, consistent with the earlier study by Fraser \& Adeoya-Osiguwa (1999). In addition, Baxendale \& Fraser (2003b) recently demonstrated that GTP $\gamma S$ significantly stimulated adenylyl cyclase activity in permeabilized cells. In the present study, when suspensions were incubated in All + GTP $\gamma$ S, there was no interference in the response to All, consistent with involvement of a G protein. However, GTP $\gamma$ S is not a specific reagent for either stimulatory or inhibitory $G$ proteins. Therefore, PT, which binds to and inhibits a number of inhibitory $\mathrm{G} \alpha$ subunits, was used to investigate whether All-induced responses involve inhibitory G proteins. The inclusion of PT abolished stimulatory responses to All in 
both uncapacitated and capacitated sperm suspensions, when assessed using both CTC and CAMP analyses, supporting the involvement of an inhibitory G protein.

This was unexpected since FPP, adenosine and calcitonin also act via $G$ protein-coupled receptors to regulate cAMP production by regulating the activity of an mAC. However, current evidence suggests that the initial stimulatory events involve stimulatory $\mathrm{G} \alpha$ subunits, while only the subsequent inhibitory events appear to involve inhibitory $\mathrm{G} \alpha$ subunits. Consistent with that, PT had no effect on the stimulatory responses to FPP and calcitonin in uncapacitated spermatozoa, but could block the inhibitory ones in capacitated suspensions (Fraser \& Adeoya-Osiguwa 1999, Fraser et al. 2001). To confirm that the present results with All + PT were valid, additional experiments evaluated the effects of treating aliquots from the same uncapacitated suspensions with AII and FPP, with or without PT. Once again, PT abolished All's acceleration of capacitation but had no inhibitory effect on responses to FPP. Therefore, different steps in the signal transduction pathways activated by FPP and All would appear to be PT-sensitive.

Recently, Baxendale and Fraser (2003b) demonstrated that ddAdo, a compound that binds to the P-site on mACs and inactivates the enzyme (Dessauer et al. 1999), significantly inhibited cAMP production in mouse spermatozoa stimulated by forskolin. In the present study, ddAdo similarly blocked responses to All, suggesting that mACs could be involved in the signalling pathway(s) activated by All. This result makes it doubtful that soluble adenylyl cyclase is involved in All-activated responses since soluble adenylyl cyclase does not appear to be regulated by compounds that act on mAC (Buck et al. 1999). However, it also seems unlikely that the AT1 receptors are acting directly on mAC since the combination of low All plus low FPP or calcitonin gives an enhanced response. The binding sites for $\mathrm{G} \alpha_{i}$ are in one cytoplasmic domain of $\mathrm{mAC}$, while those for $G \alpha_{s}$ are in another (Dessauer et al. 1999). Therefore, simultaneous All-induced activation of inhibitory $G$ subunits and FPP/calcitonin-induced activation of stimulatory $\mathrm{G} \alpha$ subunits, with both binding to mACs, would presumably result in no net activation of $\mathrm{mAC}$. Alternatively, there is evidence that some of the nine $\mathrm{mAC}$ isoforms can be stimulated by $\mathrm{G} \beta \gamma$ rather than by $\mathrm{G} \alpha$; however, $\mathrm{G} \beta \gamma$ apparently has no direct effect on $\mathrm{mAC} 3,8$ and 9 and $\mathrm{G} \beta \gamma$ activation of $\mathrm{mAC} 2$ and 4 only occurs in the presence of activated $\mathrm{G} \alpha_{\mathrm{s}}$ (Defer et al. 2000). The G $\beta \gamma$-insensitive mAC3 and 8 are the two isoforms located in the same regions as the AT1 receptor and although spermatozoa also appear to have mAC2 and 4, responses to All do not require the presence of other ligands that can activate $\mathrm{G} \alpha_{\mathrm{s}}$. Therefore, based on current knowledge of $\mathrm{G} \beta \gamma$ effects on mACs, it seems unlikely that the $\mathrm{All}-\mathrm{AT}_{1}$ receptor complex activates an inhibitory $G$ protein that then stimulates mAC directly via G $\beta \gamma$.

In an earlier study (Fraser et al. 2001) it was suggested that a plausible mechanism of action would be one where All causes a rise in the intracellular $\mathrm{Ca}^{2+}$ concentration that could then have a stimulatory effect on mAC/cAMP. Wennemuth et al. (1999), evaluating single mouse spermatozoa, reported that addition of All caused a rapid rise in intracellular $\mathrm{Ca}^{2+}$ in treated cells, and Sabeur et al. (2000) reported a similar response in equine spermatozoa. This still does not identify the precise mechanism whereby All might affect intracellular $\left[\mathrm{Ca}^{2+}\right]$. A net rise in intracellular $\left[\mathrm{Ca}^{2+}\right]$ could occur either by an increase in the entry of $\mathrm{Ca}^{2+}$ from the extracellular compartment or by a decrease in the extrusion of $\mathrm{Ca}^{2+}$ from the cell (see Wennemuth et al. 2003). In the present study, the $\mathrm{Ca}^{2+}$ channel blocker nifedipine had no detectable effect on responses to All, suggesting that voltage-operated channels that allow entry of extracellular $\mathrm{Ca}^{2+}$ are not involved. This result is consistent with earlier studies showing that nifedipine only acts on capacitated spermatozoa, blocking the acrosome reaction (Fraser \& McIntyre 1989, O'Toole et al. 1996). However, the involvement of PT-sensitive inhibitory G proteins suggests that All may be inhibiting a step, which plausibly could be $\mathrm{Ca}^{2+}$ extrusion. Therefore, future studies could be directed towards the possibility that All might somehow inhibit, for example, a $\mathrm{Ca}^{2+}$-ATPase or a $\mathrm{Na}^{+} / \mathrm{Ca}^{2+}$ exchanger.

Any hypothesis regarding the mechanism of action of All must be able to explain how, in capacitated cells, inhibition of CAMP production by calcitonin, adenosine and FPP can override the stimulation of cAMP by All, when All is used in combination with one or more of those molecules. It is difficult to envisage that responses to all these molecules involve receptor activation of $G$ proteins which then interact directly with mACs. However, if All stimulates mAC activity indirectly, for example as a result of increases in intracellular $\mathrm{Ca}^{2+}$, it is possible to provide a plausible explanation for the dominance of the inhibitory responses. In capacitated cells, calcitonin, adenosine and FPP bind to their specific receptors, resulting in activation of inhibitory $\mathrm{G}$ proteins; the binding of the latter to the target $\mathrm{mACs}$ would cause conformational changes in $\mathrm{mACs}$, rendering them inactive. Any rises in intracellular $\mathrm{Ca}^{2+}$ elicited by All would be ineffective in stimulating cAMP production because the mACs would be in an inactive state. Experimental evidence for the effectiveness of FPP and calcitonin in suppressing responses to All can be seen in some sperm samples obtained from infertility patients (see Fig. 10 in Fraser \& Osiguwa 2004). Some of those samples appeared to be at rather advanced stages of capacitation before incubation in the presence of FPP, calcitonin and All, used individually and in combination. In several samples All actually stimulated acrosome loss within the $1 \mathrm{~h}$ of incubation, compared with the untreated control, a response consistent with continuous stimulation of cAMP production. However, this response to All was abolished when the three peptides were used in combination on the same suspensions.

In conclusion, the new evidence presented here indicates that All's stimulation of cAMP in both uncapacitated and capacitated mouse sperm suspensions involves 
PT-sensitive inhibitory $G$ proteins. Although the ultimate effect appears to involve stimulation of $\mathrm{mAC}$, as evidenced by the ability of ddAdo to block All-induced responses detected by both CTC and CAMP analysis, it seems likely that this is an indirect effect. A plausible mechanism of action would involve All causing a modest rise in intracellular $\mathrm{Ca}^{2+}$, which could then stimulate $\mathrm{mAC}$ activity. This would be consistent with the evidence presented here that All requires the presence of extracellular $\mathrm{Ca}^{2+}$ in order to elicit responses. The fact that FPP, adenosine, calcitonin and All can all affect the production of cAMP in mammalian spermatozoa during capacitation, using different specific receptors and pathways to reach the same endpoint, suggests that this second messenger plays a pivotal role in sperm physiology.

\section{Acknowledgements}

This work was supported by a grant to L R F from the Biotechnology and Biological Sciences Research Council. We thank Dr Susan Adeoya-Osiguwa and Dr Rhona Baxendale for stimulating and constructive suggestions regarding this study.

\section{References}

Adeoya-Osiguwa SA \& Fraser LR 2000 Fertilization promoting peptide and adenosine, acting as first messengers, regulate cAMP production and consequent protein tyrosine phosphorylation in a capacitation-dependent manner. Molecular Reproduction and Development 57 384-392.

Adeoya-Osiguwa SA \& Fraser LR 2003 Calcitonin acts as a first messenger to regulate adenylyl cyclase/cAMP and mammalian sperm function. Molecular Reproduction and Development 65 228-236.

Baxendale RW \& Fraser LR 2003a Immunolocalization of multiple $\mathrm{G} \alpha$ subunits in mammalian spermatozoa and additional evidence for $\mathrm{G} \alpha_{\mathrm{s}}$. Molecular Reproduction and Development 65 104-113.

Baxendale RW \& Fraser LR 2003b Evidence for multiple distinctly localized adenylyl cyclase isoforms in mammalian spermatozoa. Molecular Reproduction and Development 66 181-189.

Buck J, Sinclair ML, Schapal L, Cann MJ \& Levin LR 1999 Cytosolic adenylyl cyclase defines a unique signaling molecule in mammals. PNAS 96 79-84.

Defer N, Best-Belpomme M \& Hanoune J 2000 Tissue specificity and physiological relevance of various isoforms of adenylyl cyclase. American Journal of Physiology Renal Physiology 279 F400-F416.

Dessauer CW, Tesmer JJG, Sprang SR \& Gilman AG 1999 The interactions of adenylate cyclases with P-site inhibitors. Trends in Pharmacological Sciences 20 205-210.

Fraser LR $1982 \mathrm{Ca}^{2+}$ is required for mouse sperm capacitation and fertilization in vitro. Journal of Andrology 3 412-419.

Fraser LR 1984 Mouse sperm capacitation in vitro involves loss of a surface-associated inhibitory component. Journal of Reproduction and Fertility 72 373-384.

Fraser LR 1987 Minimum and maximum extracellular Ca2 + requirements during mouse sperm capacitation and fertilization in vitro. Journal of Reproduction and Fertility 81 77-89.

Fraser LR 1993 In vitro capacitation and fertilization. Methods in Enzymology 225 239-253.

Fraser LR \& McIntyre K 1989 Calcium channel antagonists modulate the acrosome reaction but not capacitation in mouse spermatozoa. Journal of Reproduction and Fertility 86 223-233.
Fraser LR \& Adeoya-Osiguwa SA 1999 Modulation of adenylyl cyclase by FPP and adenosine involves stimulatory and inhibitory adenosine receptors and G proteins. Molecular Reproduction and Development $\mathbf{5 3}$ 459-471.

Fraser LR \& Osiguwa OO 2004 Human sperm responses to calcitonin, angiotensin II and FPP in prepared semen samples from normal donors and infertility patients. Human Reproduction 19 596-606.

Fraser LR, Pondel MC \& Vinson GP 2001 Calcitonin, angiotensin II and FPP significantly modulate mouse sperm function. Molecular Human Reproduction 7 245-253.

Fraser LR, Adeoya-Osiguwa SA \& Baxendale RW 2003 First messenger regulation of capacitation via $G$ protein-coupled mechanisms: a tale of serendipity and discovery. Molecular Human Reproduction 9 739-748.

Green CM, Cockle SM, Watson PF \& Fraser LR 1994 Stimulating effect of pyroglutamylglutamylprolineamide, a prostatic TRHrelated tripeptide, on mouse sperm capacitation and fertilizing ability in vitro. Molecular Reproduction and Development 38 $215-221$.

Green CM, Cockle SM, Watson PF \& Fraser LR 1996 A possible mechanism of action for fertilization promoting peptide, a TRHrelated tripeptide that promotes capacitation and fertilizing ability in mammalian spermatozoa. Molecular Reproduction and Development 45 244-252.

Hanoune J \& Defer N 2001 Regulation and role of adenylyl cyclase isoforms. Annual Review of Pharmacology and Toxicology 41 145-174.

Mededovic S \& Fraser LR 2004 Angiotensin II stimulates cAMP production and protein tyrosine phosphorylation in mouse spermatozoa. Reproduction $127601-612$.

O'Mahony OH, Djahanbahkch O, Mahmood T, Puddefoot JR \& Vinson GP 2000 Angiotensin II in human seminal fluid. Human Reproduction 15 1345-1349.

O'Toole CMB, Roldan ERS \& Fraser LR 1996 A role for $\mathrm{Ca}^{2+}$ channels in the signal transduction pathway leading to acrosomal exocytosis in human spermatozoa. Molecular Reproduction and Development 45 204-211.

Sabeur K, Vo AT \& Ball BO 2000 Effects of angiotensin II on the acrosome reaction in equine spermatozoa. Journal of Reproduction and Fertility 120 135-142.

Sayeski PP, Ali MS, Semeniuk J, Doan TN \& Bernstein KE 1998 Angiotensin II signal transduction pathways. Regulatory Peptides 78 19-29.

Snedecor GW \& Cochran WG 1980 In Statistical Methods, 7th edn. Ames: lowa State University Press.

Vinson GP, Saridogan E, Puddefoot JR \& Djahanbakhch O 1997 Tissue renin-angiotensin systems and reproduction. Human Reproduction 12 651-662.

Wennemuth G, Babcock DF \& Hille B 1999 Distribution and function of angiotensin II receptors in mouse spermatozoa. Andrologia $31323-325$.

Wennemuth G, Babcock DF \& Hille B 2003 Calcium clearance mechanisms of mouse sperm. Journal of General Physiology 122 115-128.

Yanagimachi R 1994 Mammalian fertilization. In The Physiology of Reproduction, 2nd edn, pp 189-317. Eds E Knobil \& JD Neil. New York: Raven Press.

Received 10 August 2004

First decision 30 September 2004

Accepted 21 October 2004 